\title{
Effects of chlorocholine chloride and paclobutrazol on cassava (Manihot esculenta Crantz cv. Rocha) plant growth and tuberous root quality
}

\author{
Medina, R.; A. Burgos (ex aequo); V. Difranco; L. Mroginski and P. Cenóz
}

\begin{abstract}
SUMMARY
The effects of chlorocholine chloride (CCC) and paclobutrazol (PBZ) foliar application on shoot and root parameters of cassava field-grown plants were studied (0, 45 and $90 \mathrm{mg}$ active ingredient per plant). CCC and PBZ reduced total plant and first branch height, aerial fresh mass and tuberous root number. PBZ delayed branching and significantly decreased tuberous root fresh mass, while CCC caused no modifications in these parameters. In addition, CCC and PBZ treatments did not modify tuberous root diameter, while PBZ reduced tuberous root length significantly. Starch content was increased by both growth regulators at the lower dose, whereas dry matter content was increased only by CCC. In conclusion, CCC suppresses excessive vegetative growth, favours quality attributes and does not alter yield, hence improving harvest index. Although PBZ at a low dose increases the starch content and harvest index, its effects on other parameters are undesirable.
\end{abstract}

Keywords: chlorocholine chloride, Manihot esculenta, paclobutrazol, starch, yield

Medina, R.; A. Burgos (ex aequo); V. Difranco; L. Mroginski y P. Cenóz, 2012. Efectos del cloruro de cloro colina y el paclobutrazol sobre el crecimiento de plantas y la calidad de raíces tuberosas de mandioca (Manihot esculenta Crantz cv. Rocha). Agriscientia XXIX: 51-58

\section{RESUMEN}

Se estudiaron los efectos de la aplicación foliar del cloruro de cloro colina (CCC) y del paclobutrazol (PBZ) sobre parámetros de crecimiento aéreo y radical de plantas de mandioca cultivadas a campo $(0,45$ y $90 \mathrm{mg}$ de principio activo por planta). El CCC y el PBZ redujeron la altura total de las plantas y la altura de la primera ramificación, el peso fresco de los órganos aéreos y el número de raíces tuberosas por planta. El PBZ retrasó la ocurrencia de la ramificación y causó reducciones significativas del peso fresco de las raíces tuberosas, mientras que el CCC no afectó dichos parámetros. Los tratamientos con CCC y PBZ no modificaron el diámetro de las raíces tuberosas, aunque el PBZ redujo significativamente su longitud. El contenido de almidón de raíces tuberosas se incrementó por la aplicación de ambos reguladores del 
crecimiento en su dosis mínima; sin embargo, el contenido de materia seca de estas sólo fue aumentado por el tratamiento con CCC. En conclusión, el CCC evita el crecimiento vegetativo excesivo, favorece los atributos de calidad de raíces tuberosas sin afectar el rendimiento y mejora el índice de cosecha. Si bien el PBZ en bajas concentraciones incrementa el contenido de almidón de las raíces tuberosas y el índice de cosecha, sus efectos sobre otros parámetros son indeseables.

Palabras clave: almidón, cloruro de cloro colina, Manihot esculenta, paclobutrazol, rendimiento

R. Medina and L. Mroginski (Instituto de Botánica del Nordeste, CONICET), R. Medina, A. Burgos, V. Difranco, L. Mroginski and P. Cenóz, Campo Didáctico-Experimental de la Facultad de Ciencias Agrarias, Universidad Nacional del Nordeste (UNNE). Sargento Cabral 2131, 3400, Corrientes, Argentina. Corresponding author: ricardomedina@ agr.unne.edu.ar

\section{INTRODUCTION}

Cassava (Manihot esculenta Crantz) is a perennial shrub of the Euphorbiaceae family, cultivated mainly for its fleshy tuberous roots, and is one of the most important sources of food energy and industrial raw materials in tropical and subtropical regions (Santisopasri et al., 2001). Cassava is often grown under low-input/ low-output production systems, resulting in low yields; therefore, new alternative practices aimed to improve yield and quality are required.

Plant growth retardants, such as chlorocholine chloride (CCC: 2-chloroethyl trimethyl ammonium chloride) and paclobutrazol (PBZ: [(2R, 3R + 2S, 3S)-1-(4-chloro-phenyl) 4,4-dymethyl-2-(1,2,4-triazol-1-yl)-pentan-3-ol]), which are traditionally used in crop field management with many purposes, often have a beneficial effect on quantity and quality of harvestable products (Šimko, 1994; Tsegaw \& Hammes, 2004, 2005).

CCC induces a reduction in aerial organ growth, and increases yield and tuber dry matter content in potato plants (Radwan et al., 1971; Wang et al., 2010). PBZ improves potato tuber yield by partitioning more assimilates to the tubers and increases starch accumulation in the tuber tissue (Tsegaw \& Hammes, 2005). It has also been reported that PBZ treatment significantly increases tuber fresh mass of potato, dry matter content, and specific gravity, regardless of the method of application (spraying or drenching) (Tsegaw \& Hammes, 2004). Other triazole compounds such as Triadimefon (TDM) and Hexaconazole (HEX) enhance tuberous root yield and starch content throughout the growing season in cassava plants (Gomathinayagam et al., 2007).
In the present study, the effects of foliar application of CCC and PBZ on several biometric parameters of cassava field-grown plants were analyzed. Our purpose was to examine whether these plant growth retardants could regulate aerial growth as well as tuberous root yield, tuberous root dry matter and starch content of cassava plants.

\section{MATERIALS AND METHODS}

\section{Plant material and experimental design}

Cassava plants (cv. Rocha) were cultivated during the 2006-2007 growing season at the experimental farm of the Facultad de Ciencias Agrarias, Universidad Nacional del Nordeste

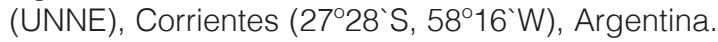
The 'Rocha' cultivar is characterized by a decumbent growth habit, an average plant height of $2 \mathrm{~m}$ and a first branching height that exceeds 1 $\mathrm{m}$ (unpublished data). The soil of the experimental site is an alfic, mixed hyperthermic Udipsamment (Escobar et al., 1994), and the climate is subtropical with an annual precipitation of $1500 \mathrm{~mm}$ and an average annual temperature of $21.5^{\circ} \mathrm{C}$ (Bruniard, 2000).

Each stem cutting was horizontally planted in a $1.0 \times 1.0 \mathrm{~m}$ plot to a depth of $5 \mathrm{~cm}$ and the experiment was carried out without nutritional or water restrictions. The amounts of fertilizer needed to drive the crop without nutritional limitations were calculated considering the results obtained by chemical analysis of the experimental site soil (Table 1) and crop requirements reported by Howeler (1981).

The results of soil analysis showed that it had low fertility because of its low content of nitrogen, 
Table 1 Chemical analysis of experimental site soil located in the farm of the Facultad de Ciencias Agrarias, Universidad Nacional del

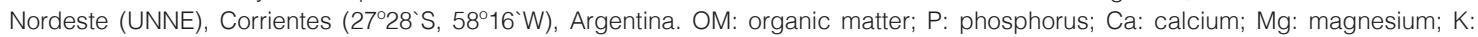
potassium

\begin{tabular}{ccccccc}
\hline $\begin{array}{c}\text { Depth } \\
\mathrm{cm}\end{array}$ & $\mathrm{pH}$ & $\begin{array}{c}\mathrm{OM} \\
\%\end{array}$ & $\begin{array}{c}\mathrm{P} \\
\mathrm{ppm}\end{array}$ & $\begin{array}{c}\mathrm{Ca} \\
\mathrm{mEq} .100 \mathrm{~g}^{-1}\end{array}$ & $\begin{array}{c}\mathrm{Mg} \\
\mathrm{mEq} .100 \mathrm{~g}^{-1}\end{array}$ & $\begin{array}{c}\mathrm{K} \\
\mathrm{mEq} .100 \mathrm{~g}^{-1}\end{array}$ \\
\hline $0-10$ & 5.55 & 0.78 & 11.64 & 1.19 & 0.40 & 0.13 \\
$10-20$ & 5.47 & 0.50 & 11.01 & 1.19 & 0.40 & 0.10 \\
\hline
\end{tabular}

therefore the calculations were made for their input. Fertilization was done with ammonium nitrate (35\% $\mathrm{N})$ at $13 \mathrm{~g}$ of fertilizer per plant in two applications, at 45 days $(6.5 \mathrm{~g})$ and 75 days of planting $(6.5 \mathrm{~g})$. Phosphorus and potassium supply was not needed because their levels in soil (Table 1) were adequate for cassava crops according Howeler (1981).

Table 2 shows the annual distribution of rainfall in the experimental site (Corrientes, Argentina) during the years 2006 and 2007.

Forty days after planting (DAP), plants (20-cmlong and 9 expanded leaves) were treated with CCC or PBZ at rates of either 45 or $90 \mathrm{mg}$ of active ingredient (a.i.) per plant at 9 AM in the morning when the dew had dried. Relative air humidity was $50 \%$ upon application. Both growth retardants were applied as a foliar spray using the commercial formulations Cotton Stop (750 g a.i. CCC L-1) and Cultar (250 g a.i. PBZ $\mathrm{L}^{-1}$ ). To this end, they were diluted in distilled water at $5000 \mathrm{mg} \mathrm{L}^{-1}$, and 144 or $288 \mathrm{ml}$ solution per plant were applied according to the rates, using an atomizer. Control plants were sprayed with distilled water of equal volume.

For this experiment we used a completely randomised block design, in which each block consisted of five treatments, with four replications. Twenty plants per treatment (four plants per replicate) were assessed.

\section{Data recording and statistical analysis}

Non-destructive measurements were taken on harvested plants at 100 and 220 DAP: plant height, first branching height, percentage of branching plants, number of nodes per main stem, and the average internode length.

Destructive measurements were recorded on harvested plants at 220 DAP: aerial fresh mass, tuberous root fresh mass per plant, number of tuberous roots per plant, tuberous root length, tuberous root diameter, fibrous root fresh mass per plant, and harvest index. Tuberous root dry matter content and tuberous root starch content were evaluated in a representative root sample and determined according to Krochmal and Kilbride (1966).

The Contrast Test was used to verify whether the differences between control plants and each of the treatments were statistically significant (Montgomery, 1997). The data were analysed using the InfoStat software (InfoStat, 2009).

\section{RESULTS}

\section{Effect of CCC and PBZ application on cassava shoot growth and branching}

CCC application reduced plant height with respect to the control plants, but only a dosage of $90 \mathrm{mg} \mathrm{pl}^{-1}$ caused a significant reduction in this parameter (Figure 1; Table 3). PBZ considerably reduced plant height, regardless of the application rates (Table 3). At 220 DAP, plants treated with CCC presented a lower first branching height than control plants, while PBZ diminished first branching height only when used at the higher rate (Table 3).

CCC and PBZ had opposite effects on number of nodes per main stem: CCC tended to decrease while PBZ increased this parameter with respect to the control plants. PBZ treatment caused a drastic internode length shortening, whereas CCC caused no significant alteration in this parameter (Figure 2; Table 3).

CCC application did not vary percentage of branching plants significantly; in contrast, PBZ delayed the branching phenomenon at 100 DAP, an effect that was reverted 120 days later (Table 3).

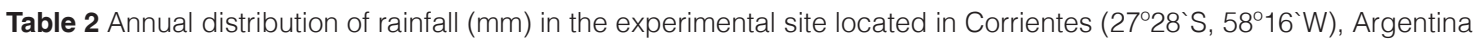
during 2006 and 2007.

\begin{tabular}{|c|c|c|c|c|c|c|c|c|c|c|c|c|c|}
\hline Year & Jan & Feb & Mar & Apr & May & Jun & Jul & Aug & Sep & Oct & Nov & Dec & Total \\
\hline 2006 & 94.3 & 18.5 & 205.0 & 157.3 & 47.7 & 96.2 & 9.5 & 20.5 & 36.3 & 198.2 & 127.2 & 144.2 & 1154,9 \\
\hline 2007 & 174.5 & 95.5 & 153.4 & 117.4 & 11.2 & 18.0 & 4.5 & 1.3 & 155.8 & 134.0 & 135.9 & 178.3 & 1179,8 \\
\hline
\end{tabular}



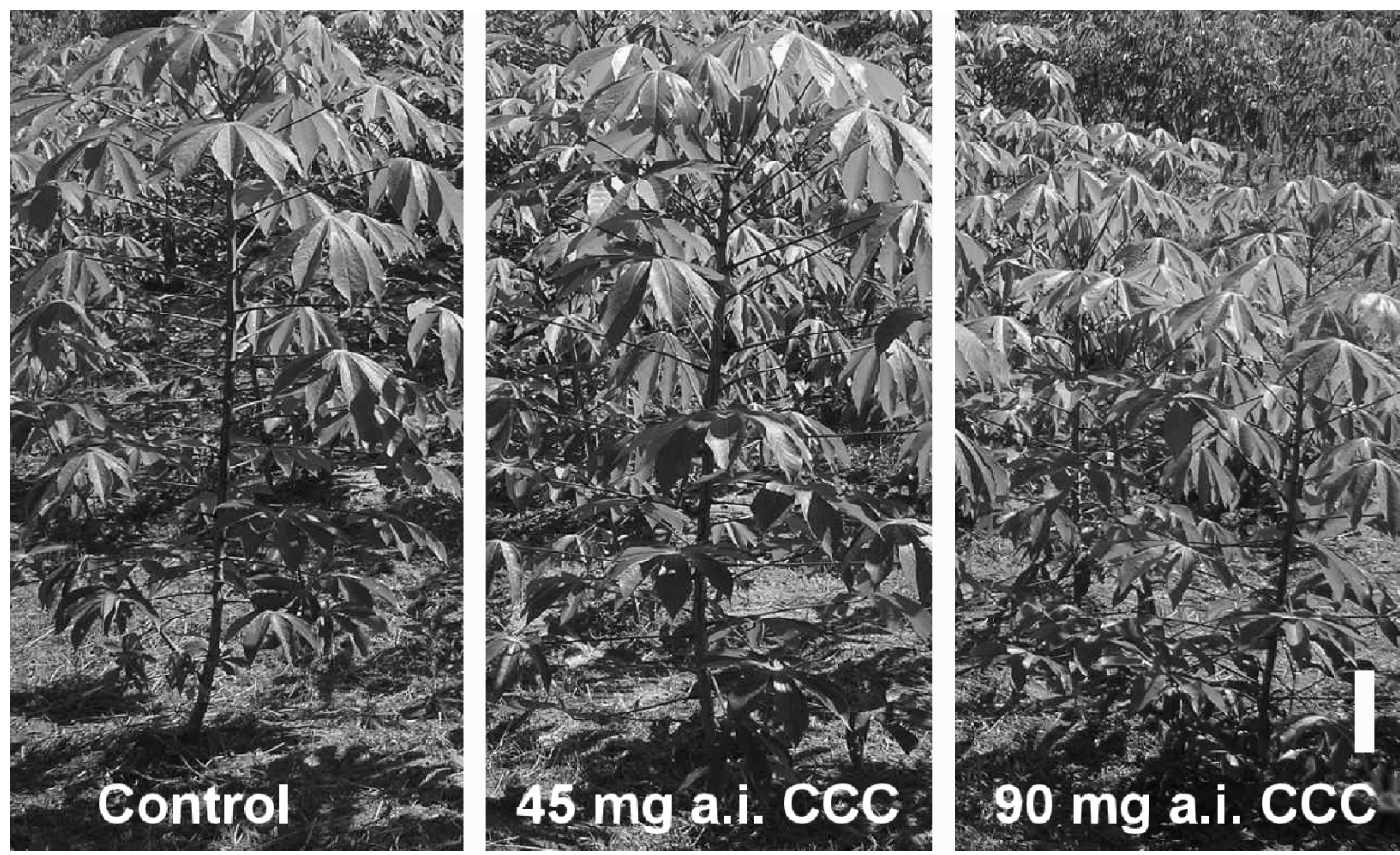

Figure 1 Effect of chlorocholine chloride (CCC) on the cassava plant height at 220 days after planting. Control plants; plants treated with $45 \mathrm{mg}$ active ingredient CCC (45 mg a.i. CCC); plants treated with $90 \mathrm{mg}$ active ingredient CCC (90 mg a.i. CCC). Bar $=10 \mathrm{~cm}$.

Table 3 Effects of chlorocholine chloride (CCC) and paclobutrazol (PBZ) foliar application on shoot growth and branching cassava field grown plants. Plant height $(\mathrm{PH})$, first branching height $(\mathrm{FBH})$, number of nodes per main stem (NNS), average internode length (IL), and aerial fresh mass (AFM) were measured at 220 days after planting (DAP). Percentage of branching plants (PBP) was recorded at 100 and 220 DAP. Corrientes, Argentina (2006/2007).

\begin{tabular}{|c|c|c|c|c|c|c|c|}
\hline \multirow{2}{*}{ Treatments ${ }^{a}$} & \multirow{2}{*}{$\mathrm{PH} \quad(\mathrm{cm})$} & \multirow{2}{*}{$\mathrm{FBH}(\mathrm{cm})$} & \multirow{2}{*}{$N_{N S}{ }^{b}$} & \multirow{2}{*}{$\mathrm{IL}(\mathrm{cm})$} & \multicolumn{2}{|c|}{$\operatorname{PBP}(\%)^{b}$} & \multirow{2}{*}{$\begin{array}{c}\text { AFM } \\
(\mathrm{g})\end{array}$} \\
\hline & & & & & at 100 DAP & at 220 DAP & \\
\hline Control & $212.1 \pm 5.7$ & $119.2 \pm 3.2$ & $47.3 \pm 1.7$ & $2.5 \pm 0.1$ & $90.9 \pm 3.1$ & $100.0 \pm 0.0$ & $1542.2 \pm 97.9$ \\
\hline CCC $45 \mathrm{mg} \mathrm{pl}^{-1}$ & $197.8 \pm 6.6$ & $107.8 \pm 3.3^{*}$ & $43.9 \pm 2.0$ & $2.5 \pm 0.1$ & $95.8 \pm 4.2$ & $100.0 \pm 0.0$ & $1082.2 \pm 108.9^{*}$ \\
\hline CCC $90 \mathrm{mg} \mathrm{pl}^{-1}$ & $187.5 \pm 4.9^{*}$ & $103.3 \pm 3.1^{*}$ & $39.2 \pm 1.3^{*}$ & $2.6 \pm 0.1$ & $90.4 \pm 6.7$ & $100.0 \pm 0.0$ & $1109.1 \pm 143.8^{*}$ \\
\hline PBZ $45 \mathrm{mg} \mathrm{pl}^{-1}$ & $188.3 \pm 6.9^{*}$ & $117.8 \pm 3.1$ & $52.1 \pm 2.5^{*}$ & $2.2 \pm 0.1^{*}$ & $52.4 \pm 5.8^{*}$ & $95.8 \pm 4.2$ & $931.6 \pm 82.1^{*}$ \\
\hline PBZ $90 \mathrm{mg} \mathrm{pl}^{-1}$ & $188.6 \pm 4.4^{*}$ & $108.8 \pm 2.3^{*}$ & $57.3 \pm 1.7^{*}$ & $1.9 \pm 0.1^{*}$ & $22.6 \pm 6.2^{*}$ & $97.2 \pm 2.8$ & $1104.4 \pm 102.4^{*}$ \\
\hline
\end{tabular}

${ }^{a}$ All numerical data are given as mean with standard errors ( \pm SE). The significance of changes in the test responses was assessed using an analysis of variance (ANOVA) followed by a contrast test.

${ }^{\mathrm{b}}$ For these parameters contrast test was carried out from squared transformed data.

Asterisk indicates statistical significance at $\mathrm{P}<0.05$.

On the other hand, CCC and PBZ reduced aerial fresh mass significantly (Table 3).

\section{Effect of CCC and PBZ application on cassava root growth}

PBZ significantly reduced fibrous root fresh mass, while CCC did not modify this parameter with respect to the control plants. Foliar spray with CCC did not cause changes in the yield (expressed as tuberous root fresh mass per plant), but significantly decreased number of tuberous roots per plant. PBZ application caused a significant decrease in tuberous root fresh mass per plant, as well as a marked decrease in number of tuberous roots per plant (Table 4). Both CCC and PBZ increased harvest index (Table 4).

The lower dose of CCC increased tuberous root dry matter content, whereas PBZ did not cause differences compared to the control. Both plant growth retardants improved tuberous root starch content at the lower dose (Table 4). Both 

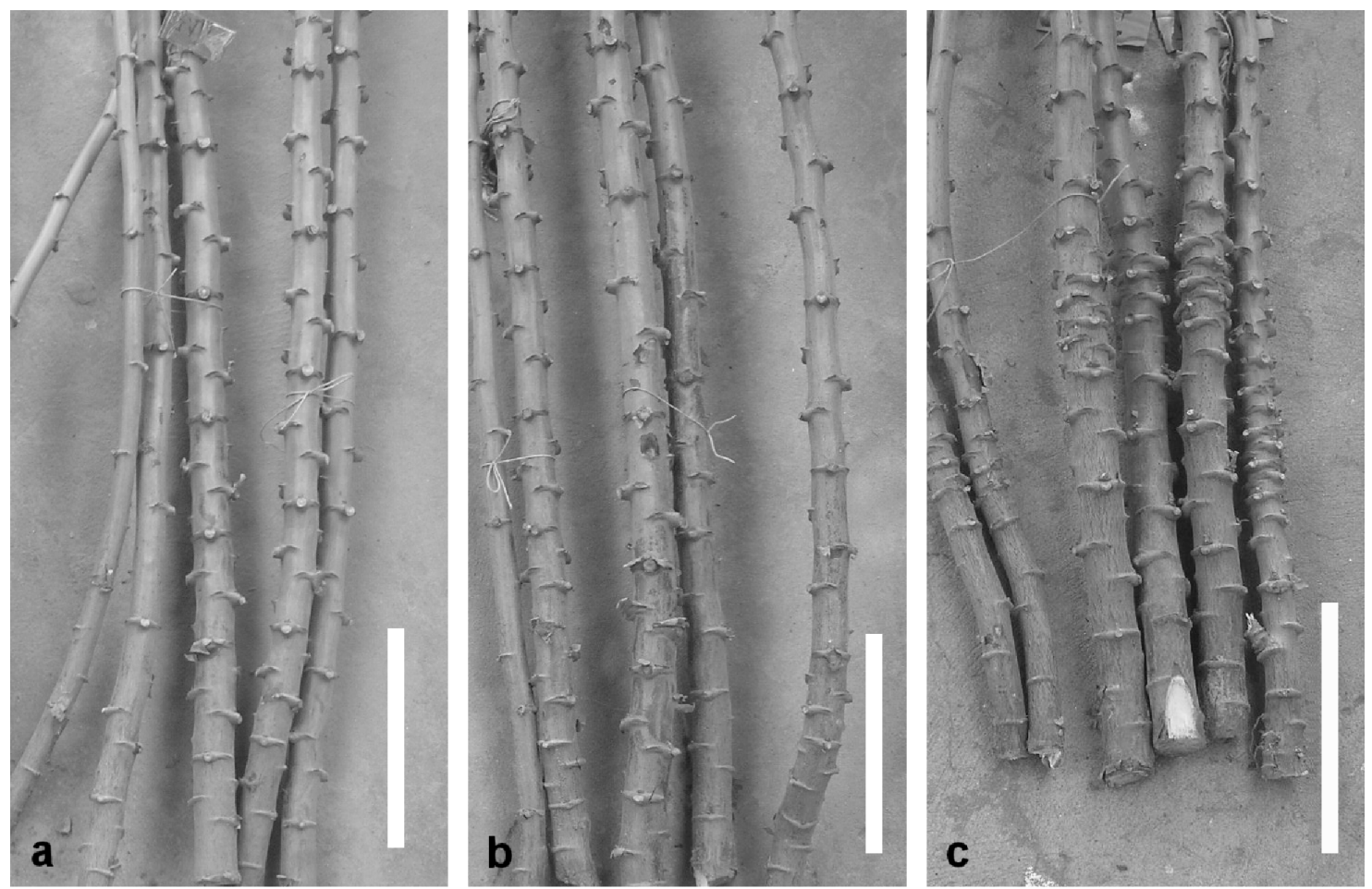

Figure 2 Effect of chlorocholine chloride (CCC) and paclobutrazol (PBZ) on the internode length of the main stem of cassava plants. a: control plants; b: CCC treated plants; c: PBZ treated plants. Bars $=17 \mathrm{~cm}$.

Table 4 Effects of chlorocholine chloride (CCC) and paclobutrazol (PBZ) foliar application on radical growth of cassava field grown plants. Fibrous roots fresh mass per plant (FRFM), tuberous roots fresh mass per plant (TRFM), harvest index (HI), number of tuberous roots per plant (NTR), tuberous roots dry matter content (TRDM), tuberous roots starch content (TRSC), and tuberous roots length (TRL) were recorded at 220 days after planting. Corrientes, Argentina (2006/2007).

\begin{tabular}{|c|c|c|c|c|c|c|c|}
\hline Treatments $^{a}$ & FRFM (g) & TRFM $(\mathrm{Kg})$ & $\mathrm{HI}$ & NTR $^{b}$ & $\operatorname{TRDM}(\%)^{b}$ & TRSC (\%) & $\mathrm{TRL}(\mathrm{cm})$ \\
\hline Control & $8.1 \pm 0.9$ & $3.8 \pm 0.2$ & $0.70 \pm 0.01$ & $13.8 \pm 1.0$ & $31.0 \pm 0.3$ & $29.6 \pm 0.3$ & $32.0 \pm 1.2$ \\
\hline CCC $45 \mathrm{mg} \mathrm{pl}^{-1}$ & $7.4 \pm 0.8$ & $3.4 \pm 0.1$ & $0.73 \pm 0.01^{*}$ & $9.9 \pm 0.8^{*}$ & $33.0 \pm 0.4^{*}$ & $31.3 \pm 0.3^{*}$ & $30.6 \pm 1.6$ \\
\hline CCC $90 \mathrm{mg} \mathrm{pl}^{-1}$ & $7.5 \pm 0.9$ & $3.5 \pm 0.4$ & $0.71 \pm 0.01^{*}$ & $10.7 \pm 1.0^{*}$ & $29.1 \pm 0.6$ & $28.1 \pm 0.6$ & $29.3 \pm 1.5$ \\
\hline PBZ $45 \mathrm{mg} \mathrm{pl}^{-1}$ & $4.4 \pm 0.7^{*}$ & $2.7 \pm 0.3^{*}$ & $0.71 \pm 0.01^{*}$ & $8.8 \pm 0.8^{*}$ & $32.6 \pm 0.9$ & $31.6 \pm 0.8^{*}$ & $28.3 \pm 1.3^{*}$ \\
\hline PBZ $90 \mathrm{mg} \mathrm{pl}^{-1}$ & $3.9 \pm 0.7^{*}$ & $2.6 \pm 0.4^{*}$ & $0.71 \pm 0.01^{*}$ & $8.8 \pm 0.9^{*}$ & $30.3 \pm 0.3$ & $29.4 \pm 0.3$ & $27.9 \pm 0.7^{*}$ \\
\hline
\end{tabular}

${ }^{a}$ All numerical data are given as mean with standard errors ( \pm SE). The significance of changes in the test responses was assessed using an analysis of variance (ANOVA) followed by a contrast test.

${ }^{b}$ For these parameters contrast test was carried out from squared transformed data.

${ }^{*}$ Asterisk indicates statistical significance at $\mathrm{P}<0.05$.

CCC and PBZ treatments did not modify tuberous root diameter (ca. $4.7 \mathrm{~cm}$; data not shown), while PBZ reduced significantly tuberous root length, regardless of the applied dose (Table 4).

\section{DISCUSSION}

Plant growth retardants, particularly onium compounds (e.g. CCC) and triazole compounds (e.g. PBZ), are able to increase the partitioning of assimilates to roots and thereby improve yield through the inhibition of gibberellin biosynthesis or action (Fletcher et al., 2000; Mansuroglu et al., 2009). In addition, they can be used to control excessive vegetative growth (Rademacher, 2000; Ghosh et al., 2010), and to increase quality attributes such as dry matter and starch content of the harvestable organ (Tsegaw \& Hammes, 2005).

The results of this work show that CCC causes a retardation effect on cassava stem elongation and therefore a reduction in plant height, thus confirming pioneer studies (Radwan et al., 1971). In cassava, PBZ application also was effective in reducing branch and plant height even at a low 
concentration, as previously described for other species (Bañon et al., 2002; Tsegaw \& Hammes, 2004; Ghosh et al., 2010). A reduction in the aerial dry mass and the partitioning of the dry matter to the canopy has also been observed in potato plants treated with PBZ and CCC (Wang et al., 2009). In our work, CCC and PBZ also reduced aerial fresh mass.

The most striking growth response observed in different species treated with PBZ and CCC is shoot growth reduction mainly by shortening the internode length (Davis \& Curry, 1991; Rossini Pinto et al., 2005). In the present work, PBZ also reduced shoot growth by decreasing the internode length; however, CCC decreased it by decreasing the node number.

It has also been demonstrated that regulation of branching can increase cassava yields until 75\% (Lian \& Cock, 1979). In our work, CCC and PBZ regulated the first branching height and PBZ also controlled branching time, which would allow adjusting crop density to achieve higher yields.

The beneficial effects of the plant growth retardants on the tuberous organ growth varied with the types and concentrations assayed (Šimko, 1993; Rayirath et al., 2009). CCC stimulates potato tuber initiation (Leclerc et al., 1994). On the other hand, high PBZ concentrations strongly reduce potato tuber mass and number (Šimko, 1994). In this work, CCC treatment did not modify tuberous root fresh mass, but significantly increased harvest index. PBZ also improved harvest index but significantly reduced tuberous root fresh mass and tuberous root number.

In addition, PBZ reduced cassava fibrous root formation like in potato nodal segments (Šimko, 1993). Probably, this effect could cause a lower nutrient uptake capacity and therefore a low ability to achieve good yields, as argued by Rieger and Scalabrelli (1990) studying Prunus persica trees treated with PBZ. CCC application did not reduce cassava fibrous root formation, apparently favouring tuberous root yield. Moreover, CCC application reduced aerial fresh mass, resulting in a higher harvest index compared to untreated cassava plants.

In potato, Tsegaw and Hammes (2004) reported that PBZ increases tuber fresh mass, dry matter content and specific gravity but reduces tuber number until $43 \%$ as compared to controls. Šimko (1994) also observed an increase in tuber yield in plants treated with PBZ. Changes in the net photosynthetic rate in potato plants induced by spraying CCC also increase crop productivity (Wang \& Xiao, 2009). In this work, PBZ caused a reduction in the tuberous root fresh mass and tuberous root number regardless of the dose, while CCC decreased tuberous root number but not tuberous root fresh mass.

Although it has been reported that PBZ causes root thickening (Tsegaw \& Hammes, 2005), neither of the growth retardants used caused root thickening in cassava tuberous roots. Only PBZ treatment caused shortening of the tuberous roots.

Plant growth retardants are considered as tuberization promoters; in fact, the application of CCC and PBZ increases starch content in potato tubers (Tsegaw \& Hammes, 2005; Sharma et al., 1998). In this work, CCC and PBZ also improved the starch content of cassava tuberous roots when $45 \mathrm{mg}$ a.i. per plant was applied; in addition, CCC increased dry matter content of the cassava tuberous roots at the same low dose. The export of the photoassimilates and the starch synthesis is reduced by the $\mathrm{GA}_{3}$ application (Booth \& Lovell 1972; Mares et al., 1981), so the beneficial action of low concentrations of plant growth retardants on the tuberous root quality could be explained by its gibberellins antagonistic action, as argued by Fletcher et al. (2000) and Mansuroglu et al. (2009).

The application of others plant growth retardants such as TDM and HEX in cassava plants enhanced photosynthetic pigments, the non-enzymatic antioxidant content and the activity of antioxidant enzymes which demonstrates its utility as an alternative agricultural practice for improving crop productivity and profitability (Gomathinayagam et al., 2007, 2008a, 2008b, 2009).

In summary, CCC is effective to control excessive vegetative growth, increase harvest index and improve tuberous root dry matter and starch content. In addition, PBZ at low doses allows increasing starch content, but its effects on others yield parameters are negative.

As cassava is an important source of industrial raw materials (Santisopasri et al., 2001), foliar CCC application at low concentrations should be considered by farmers as an alternative to improve starch root content and hence crop profitability. Furthermore, plant size regulation could allow intercropping with other species for a longer period. On the other hand, it has been previously demonstrated in pioneering studies that CCC declines quickly in vegetative parts after treatments leaving no traces when applied at low doses and that it is inactivated by cooking (Jung \& El-Fouly, 1969), properties that make CCC a promising growth regulator that offers a safe food product.

In potato, the most important tuber crop in the world, it has consistently demonstrated CCC and 
other growth retardants applications increase tuber yield and quality under field conditions, by which it has been recommended as a good tool to optimize their productivity (Radwan et al., 1971; Sharma et al., 1998; Wang et al., 2009; Wang et al., 2010). However, to corroborate the beneficial effect of CCC spraying on the yield and quality of cassava tuberous roots are still needed further evaluations before such treatments can be practiced on a large-scale, routinely and safely.

\section{ACKNOWLEDGMENTS}

We are grateful to Consejo Nacional de Investigaciones Científicas y Técnicas and Secretaría General de Ciencia y Técnica (UNNE) for the financial support. We wish to thank Jerry Paxton for his valuable contributions.

\section{REFERENCES}

Bañon, S.; A. González, E. Cano, J. Franco and J. Fernández, 2002. Growth, development and color response of potted Dianthus caryophyllus cv. Mondriaan to paclobutrazol treatment. Scientia Horticulturae 94:371-377.

Booth, A. and P. Lovell, 1972. The effect of pretreatment with gibberellic acid on the distribution of photosynthates in intact and disbudded plants of Solanum tuberosum. New Phytologist 71:795-804.

Bruniard, E., 2000. Los regímenes climáticos y la vegetación natural. Aportes para un modelo fitoclimático mundial. Academia Nacional de Geografía. Publicación Especial N 16, Buenos Aires, Argentina. 79 pp.

Davis, T. and E. Curry, 1991. Chemical regulation of vegetative growth. Critical Reviews in Plant Sciences 10:151-188.

Escobar, E.; D. Ligier, M. Melgar, H. Matteio y O. Vallejos, 1994. Mapa de suelos de los Departamentos Capital, San Cosme e Itatí de la Provincia de Corrientes, Argentina, Convenio del Instituto Nacional de Tecnología Agropecuaria / ICA y Provincia de Corrientes-Consejo Federal de Inversiones, Argentina. $125 \mathrm{pp}$.

Fletcher, A.; A. Gilley, N. Sankhla and T. Davies, 2000. Triazoles as plant growth regulators and stress protectants. Horticultural Reviews 24:55-138.

Ghosh, A.; J. Chikara, D. Chaudhary, A. Prakash, G. Boricha and A. Zala, 2010. Paclobutrazol arrests vegetative growth and unveils unexpressed yield potential of Jatropha curcas. Journal of Plant Growth Regulation 29:307-315.
Gomathinayagam, M.; C. Jaleel, M. Azooz and R. Panneerselvam, 2007. Changes in carbohydrate metabolism by trialzole growth regulators in cassava (Manihot esculenta Crantz); effects on tuber production and quality. Comptes Rendus Biologies 330:644-655.

Gomathinayagam, M.; C. Jaleel, M. Azooz and R. Panneerselvam, 2008a. Triazole induced alterations in the peroxidation of membrane lipids and antioxidant status of Manihot esculenta Crantz. Global Journal of Molecular Sciences 3:80-85.

Gomathinayagam, M.; C. Jaleel, M. Azooz and R. Panneerselvam, 2008b. Triadimefon and hexaconazole enhances the photosynthetic pigment composition of tapioca, an important tuber crop. Global Journal of Molecular Sciences 3:86-92.

Gomathinayagam, M.; C. Jaleel, M. Azooz and R. Panneerselvam, 2009. Superoxide dismutase and ascorbate peroxidase profile changes with triazole applications in Manihot esculenta Crantz. Global Journal of Molecular Sciences 4:23-28.

Howeler, R. 1981. Nutrición Mineral y fertilización de la yuca. Centro Internacional de Agricultura Tropical. Cali, Colombia. 55 pp.

InfoStat, 2009. InfoStat versión 2009 p. Grupo Infostat, Facultad de Ciencias Agropecuarias, Universidad Nacional de Córdoba, Argentina.

Jung, J. and M. El-Fouly, 1969. Some factors affecting the degradation of (2-chloroethyl)-trimethylammonium chloride by wheat plant extracts. Experientia 25:587588.

Krochmal, A. and B. Kilbride, 1966. An inexpensive laboratory method for cassava starch extraction. Journal of Agriculture of the University of Puerto Rico 50:252-253.

Leclerc, Y.; D. Donnelly and J. Seabrook, 1994. Microtuberization of layered shoots and nodal cuttings of potato: The influence of growth regulators and incubation periods. Plant Cell, Tissue and Organ Culture 37:113-120.

Lian, T. and J. Cock, 1979. Branching habit as a yield determinant in cassava. Field Crops Research 2:281290.

Mansuroglu, S.; O. Karaguzel, V. Ortacesme and M. Sayan, 2009. Effect of paclobutrazol on flowering, leaf and flower colour of Consolida orientalis. Pakistan Journal of Botany 41:2323-2332.

Mares, D; H. Marshner and A. Krauss, 1981. Effect of gibberellic acid on growth and carbohydrate metabolism of developing tubers of potato (Solanum tuberosum). Physiologia Plantarum 52:267-274.

Montgomery, D., 1997. Design and analysis of experiments, 4th Ed., Wiley, New York. 704 pp.

Rademacher, W., 2000. Growth retardants: effects 
on gibberellin biosynthesis and other metabolic pathways. Annual Review of Plant Physiology and Plant Molecular Biology 51:501-531.

Radwan, A; M. El-Fouly and N. Garas, 1971. Retarding stem elongation and stimulating dry matter production and yield of potato with chlormequat chloride (CCC). Potato Research 3:173-180.

Rayirath, U.; R. Lada, C. Caldwell, S. Asiedu, K. Sibley and A. Adams, 2009. CCC and prohexadione-Ca enhance rhizome growth and lateral bud production in rhubarb (Rheum rhabarbarum L.). Journal of Plant Growth Regulation 28:137-146.

Rieger, M. and G. Scalabrelli, 1990. Paclobutrazol, root growth hydraulic conductivity and nutrient uptake of Nemaguard peach. HortScience 25:95-98.

Rossini Pinto, A.; T. Deléo Rodrigues, I. Leite and J. Barbosa, 2005. Growth retardants on development and ornamental quality of potted 'lilliput' Zinnia elegans Jacq. Scientia Agricola 62:337-345.

Santisopasri, V.; K. Kurotjanawong, S. Chotineeranat, K. Piyachomkwan, K. Sriroth and Ch. Oates, 2001. Impact of water stress on yield and quality of cassava starch. Industrial Crops Production 13:115-129.

Sharma, N.; N. Kaur and A. Gupta, 1998. Effect of chlorocholine chloride sprays on the carbohydrate composition and activities of sucrose metabolising enzymes in potato (Solanum tuberosum L.). Plant Growth Regulation 26:97-103.

Šimko, I., 1993. Effects of kinetin, paclobutrazol and their interactions on the microtuberization of potato stem segments cultured in vitro in the light. Plant Growth Regulation 12:23-27

Šimko, I., 1994. Effect of paclobutrazol on in vitro formation of potato microtubers and their sprouting after storage. Biologia Plantarum 36:15-20.

Tsegaw, T. and P. Hammes, 2004. Response of potato grown under non-inductive condition to paclobutrazol: shoot growth, chlorophyll content, net photosynthesis, assimilate partitioning, tuber yield, quality, and dormancy. Plant Growth Regulation 43:227-236.

Tsegaw, T. and P. Hammes, 2005. Growth responses of potato (Solanum tuberosum) grown in a hot tropical lowland to applied paclobutrazol: 2. Tuber attributes. New Zealand Journal of Crop and Horticultural Science 33:43-51.

Wang, H; H. Li, F. Liu and L. Xiao, 2009. Chlorocholine chloride application effects on photosynthetic capacity and photoassimilates partitioning in potato (Solanum tuberosum L.). Scientia Horticulturae 119:113-116.

Wang, H. and L. Xiao, 2009. Effects of chlorocholine chloride on phytohormones and photosynthetic characteristics in potato (Solanum tuberosum L.). Journal of Plant Growth Regulation 28:21-27.

Wang, H.; L. Xiao, J. Tong and F. Liu, 2010. Foliar application of chlorocholine chloride improves leaf mineral nutrition, antioxidant enzyme activity, and tuber yield of potato (Solanum tuberosum L.). Scientia Horticulturae 125: 521-523. 